\title{
Profeten Jeremias og genopbyggelsen af national identitet
}

\author{
Et aspekt af teologien i Jeremias' Bog ${ }^{1}$
}

\author{
Lektor, ph.d. Else K. Holt
}

\begin{abstract}
The Book of Jeremiah can be read as a contribution to the struggle for the rebuilding of the exilic and post-exilic nation of Israel. Based on social-anthropological theories about the conditions of the life of refugees, presented by the American biblical scholar Daniel SmithChristopher, the polyphonic Book of Jeremiah is presented as a text with a "V-structure": The first half of the book represents a dystopian disclosure of Israel's culpability while the second offers a utopian message of hope for the nation. Such a message needs authority, and this authority is reinforced by the strong identification of the prophet with (the word of) God. This article presents the literary persona of the prophet as partly dissimilated from the people and assimilated to God and partly in conflict with God as a role model for the people in its suffering.
\end{abstract}

Key words: Book of Jeremiah - Old Testament theology - exile - refugee studies - Jeremiah's confessions - Book of Consolation

Profeten Jeremias' Bog er på mange måder en overset bog i Det Gamle Testamente, både folkeligt og blandt fagteologer - og det er synd, men også forståeligt. For det første er det nemlig en ganske stor og uoverskuelig bog med sine 52 lange kapitler. For det andet er det for en stor dels vedkommende en ganske ubehagelig bog med et voldsomt budskab om synd, fordømmelse og straf og med et tilsvarende voldsomt sprogligt udtryk, fuldt af krig, vold, seksuel chikane, jalousi og anden urimelighed. Der er meget lidt ved Jeremiasbogen, der umiddelbart inviterer til lystlæsning, ikke mange passager à la de elskede dele af det næsten samtidige skrift Deuterojesaja. Og for det tredje er der meget få dele af Jeremiasbogen, som umiddelbart peger hen mod Kristus, og som derfor har påkaldt sig kristne eksegeters interesse - igen til forskel fra Deuterojesaja og hans tale om Herrens lidende tjener.

1. Oprindeligt skrevet som foredrag til Båringmødet 2006; let revideret. 
Ikke desto mindre er Jeremiasbogen en bog, det er værd at beskæftige sig med, også for en teologisk betragtning. De overvejelser over Jeremiasbogens teologi, jeg vil præsentere i det følgende, har som deres metodiske spørgehorisont en interesse for bogens funktion $\mathrm{i}$ (gen)opbyggelsen af Juda i tiden efter Jerusalems fald i $587 \mathrm{f}$.Kr. Udgangspunktet er, at Jeremiasbogen kan læses som et indlæg i den kamp om en genopbygning af en national og religiøs identitet, som fandt sted i perioden. Denne interesse for identitetsskabelse er jeg på ingen måde alene om i den gammeltestamentlige forskerverden, ${ }^{2}$ og heller ikke mere specifikt i den nyeste Jeremiasforskning. ${ }^{3}$ Mit bidrag har derfor som mål at præsentere denne forskning for et dansk publikum og dertil at føje mine egne overvejelser over, hvordan netop Jeremiasbogen har kunnet bidrage i afklarings- og genopbygningsprocessen. En sådan læsestrategi kan betegnes som en litterært-teologisk læsning, snarere end en historisk-kritisk, skønt udgangspunktet for læsningen netop er socialantropologisk.

Før vi når så langt, er der imidlertid nogle introducerende bemærkninger, som jeg finder nødvendige pga. Jeremiasbogens størrelse og kompositoriske kompleksitet. Jeremiasbogens teologier kommer nemlig ikke alene frem på overfladeplanet, i dens orakler og fortællinger. De præsenteres også - og måske endda især - $\mathrm{i}$ dens komposition og interne teologiske drøftelser.

\section{Baggrund}

Jeremiasbogen tillægges traditionelt en person, profeten Jeremias, om hvem det fortælles, at han levede i Juda i tiden forud for babylonernes ødelæggelse af Jerusalem og deres indtagelse af hele Juda i 587 f.Kr. Jeremias forkynder hér den guddommelige vrede over judæernes frafald fra deres nationale gud, Jahve, og da babylonerhæren belejrer Jerusalem, formaner han til overgivelse til fjenden - babylonerne er nemlig Guds straffende redskab. Kong Sidkija og de ledende kredse ved hoffet og i byen vil imidlertid ikke høre på Jeremias' gode politiske råd, og derfor falder byen, kongen bliver taget til fange og sendt i eksil sammen med hoffet og byens bedste borgere - mens Je-

2. Se fx Kåre Berge, "Etnisitet og religiøs identitet i Patriark- og Utferdsfortellingen: Nyere forskning, etnisk teori, og etniske uttrykksformeri noen bibeltekster", DTT 69 (2006), 184-201.

3. Der findes ikke noget egentligt standardværk vedr. denne tilgang til Jeremias' Bog; forskningen er endnu under udvikling, og diskussionen foregår primært i form af mundtlige kongresindlæg, fx ved det amerikanske Society of Biblical Literature's årsmøder. 
remias bliver tilbage hos de efterladte i landet og kommer under den babyloniske guvernørs beskyttelse. Dog, det hjælper ham ikke meget. Efter et judæisk oprør mod babylonerne flygter oprørerne mod Jeremias' råd til Egypten (!) og tager Jeremias med sig (Jer 42,1-43,7).

Herfra hører vi så om et sidste profetisk opgør med de oprørske judæere, der fremturer i deres afgudsdyrkelse, sågar af en kvindelig guddom, Himlens dronning, og vi forstår, at Guds straf, det babyloniske eksil, er retfærdig (Jer 44). Jeremias' Bog i den skikkelse, som vi finder i den hebraiske bibel og dermed også i den danske oversættelse, afsluttes dog med en række guddommelige straffetaler mod Judas naboer (Jer 46-51), der munder ud i en voldsom domstale om den symbolske fjende over alle fjender, Babylon (Jer 50-51). I disse taler mod Judas modstandere ligger der gemt et håb om genoprettelse for Juda selv. ${ }^{4}$

Alting tyder imidlertid på, at denne fortælling handler om noget helt andet - til trods for at den fremstår som en autentisk fortælling om, hvad en bestemt autentisk person, profeten Jeremias gjorde og sagde og mente og troede på i årene op til Jerusalems fald. Profeten kan ganske vist godt være en historisk person i triviel forstand - ja har sandsynligvis været det - men det har vi ikke nogen sikkerhed for. Og i sidste ende er det i virkeligheden også ganske ligegyldigt. Den betydning eller autoritet, man måtte tillægge hans budskab, afhænger ikke af hans person, men derimod af den autoritet, som budskabet har, fordi det er en del af kanon. ${ }^{5}$

\section{Teksthistorie}

Når profeten Jeremias fortoner sig som egentlig forfatter til hele skriftet - og det har han faktisk gjort i de sidste ca. 100 års forskning ${ }^{6}$ - så kommer der en teksthistorie frem, som afspejler, at de gammeltestamentlige tekster (og for den sags skyld også de nytestamentlige) var levende og foranderlige i de første århundreder. Først med kanonise-

4. Se hertil Else K. Holt, "The Meaning of an Inclusio: A Theological Interpretation of the Book of Jeremiah MT", SJOT 17 (2003), 183-205.

5. Se hertil også $\mathrm{fx}_{\mathrm{x}}$ Joseph M. Henderson, "Jeremiah $2-10$ as a Unified Literary Composition: Evidence of Dramatic Portrayal and Narrative Progression”, $U_{p}$ rooting and Planting, red. John Goldingay (London: Continuum / T\&T Clark 2007), 116-152. Om den biografiske læsning af Jeremias' Bog, se Else K. Holt, "Den ensomme profet - eller: Hvorfor skal man studere Jeremias' biografi?" Historie og konstruktion, red. M. Müller og T.L.Thompson (København: Museum Tusculanums Forlag 2005), 192-205.

6. Se allerede Sigmund Mowinckels epokegørende skrift, Zur Komposition des Buches Jeremia (Videnskapsselskapets Skrifter. II. Hist.-Filos. Klasse. 1913. No. 5, Kristiania: Jacob Dybwad 1914). 
ringen af de bibelske tekster forstenede de. Det kan vi se, bl.a. ved at sammenligne den hebraiske (MT) og den græske (LXX) udgave af Jeremiasbogen. Den hebraiske version i den meget sene udgave, vi har den overleveret $i$, er ca. 1/7 længere end den græske, en udvidelse der altså er sket fra den græske oversættelse blev lavet i det 2. århundrede f.Kr. og til den hebraiske tekst blev kanoniseret i 1. århundrede e.Kr. ${ }^{7}$ Også Qumranskrifterne afspejler dels den græske, dels den hebraiske Jeremiastekst.

Teksterne er altså levende og foranderlige, og vi kan gå ud fra, at de forandringer, der finder sted, sker for at bevare - og besvare - forbindelsen til den aktuelle virkelighed. Det, teksterne skal, er at forkynde Guds ord ind i en ny virkelighed. Gudsordet opfattes ikke som statisk og uforanderligt, men som virksomt, virkeligt, aktuelt. Der er langt fra vor tids bogkonservatisme og dermed tankekonservatisme og til det ønske om fornyet gennemtænkning og re-interpretation, som vi finder i mange af de gammeltestamentlige skrifter.

Med den amerikanske ekseget Mark Biddle kan man beskrive Jeremiasbogen som et polyfonisk musikstykke. ${ }^{8}$ Profetorakler, prædikener og fortællinger samt teologiske overvejelser i visdomsstil spiller sammen og danner i fællesskab et værk, der er fuldt af samklang, men også af disharmonier. Der er udsagn i Jeremiasbogen, som direkte modsiger hinanden. ${ }^{9}$ Men de disharmoniske "melodistumper" er med til at skabe det overordnede teologiske budskab. Sagt med andre ord: forskellige tiders brugere af bogen har føjet deres egne overvejelser til. Man har diskuteret inden for bogen, i modsætning til nutidens diskussion af det bibelske budskab, der er henvist til at finde sted uden for bogen. På den måde holdt man det guddommelige budskab varmt og virksomt - guddommen indgår så at sige $\mathrm{i}$ en diskussion med menneskene.

7. Til forholdet mellem MT og LXX, se fx J. Gerald Janzen, Studies in the Text of Jeremiah (Cambridge Mass: Harvard University Press 1973); Emanuel Tov, "Some Aspects of the Textual and Literary History of the Book of Jeremiah" Le Livre de Jérémie: Le Prophète et son Milieu - Les Oracles et leur Transmission, red. P.-M. Bogaert (Leuven: Peeters/ Leuven University Press 1981), 145-167; Sven Soderlund, The Greek Text of Jeremiah: A Revised Hypothesis (JSOTSS 47, Sheffield: JSOT Press 1985).

8. Mark E. Biddle, Polyphony and Symphony in Prophetic Literature: Rereading Jeremiah 7-20 (Studies in Old Testament Interpretation 2, Macon GA: Mercer University Press 1996).

9. Se fx modifikationen af domsudsagnene Jer 5,14-19. 


\section{Den historiske baggrund}

Jeremiasbogens historiske baggrund er altså ikke entydigt og udelukkende de sidste ca. 25 år før Jerusalems fald og eksilets begyndelse, profeten Jeremias' aktive tid if. bogens indledning. Men begivenhederne i 587 f.Kr., sådan som de er beskrevet dels i 2 Kong 25, dels og langt mere detaljeret - i Jer 37-42; 52, er alligevel af helt afgørende betydning for den. Det er Jerusalems fald med kongehusets sammenbrud og nedsmeltningen i den almene tillid til, at Gud er ubetinget med judæerne, der danner udgangspunktet for bogens budskab.

Efter byens fald føres - efter sædvanlig nærorientalsk skik - alle af betydning i den besejrede by, kongehus, adel og hof, samt en stor del af "borgerskabet", først og fremmest præster, købmænd og håndværkere, i eksil i Babylon, mens landbefolkningen formentlig bliver tilbage i landet og arbejder videre som den altid har gjort, nu blot for andre herrer. For landbefolkningen kan det være ligegyldigt, hvem man arbejder for og betaler skatter til; nationalfølelse er ikke vigtig for landarbejdere og småkvægsnomader. Mellemklassen, der bliver ført til Babylon, kan også leve videre nogenlunde som altid; købmænd handler, håndværkere laver deres håndværk, og hvad angår præsterne ligner tempeltjenesten formentlig sig selv i det store religiøse og kulturelle koinonía, som den nære Orient udgør. Kongen og hoffet er naturligvis sat ud af spillet - kongen endda if. Jeremiasbogen med store personlige omkostninger (Jer 39,1-10). Men hofembedsmænd og skrivere er der også altid brug for, og egentlig er der ingen grund til at tage forandringerne så tungt.

Alligevel har vi vidnesbyrd om, at vældige overvejelser går i gang $\mathrm{i}$ det jødiske eksilsamfund; store dele af Det Gamle Testamente kan i sidste ende ses som et svar på eksilproblematikken. Man er for det første tvunget til at overveje, hvorfor Judas Gud er blevet slået og gjort tempelhjemløs, og for det andet, hvordan man skal forholde sig som fremmed etnisk gruppe i et fremmed land med fremmede guder. Endelig må vi ikke glemme, at også de eksileredes tilbagevenden til Juda i persertiden skabte store spændinger mellem de hjemvendende og landet beboere, jf. fx Ezra 9-10.10

Hvordan babylonerne behandlede deres indvandrere er et omdiskuteret spørgsmål; men at der var grupper af intellektuelle og præster, der gjorde sig de nævnte tanker, kan næppe afvises. Dertil vidner Det Gamle Testamente alt for stærkt om disse problemer, og mange ser de forskellige teologiske positioner, som findes i Det Gamle Testa-

10. Se videre John Hill, "The Book of Jeremiah (MT) and its Early Second Temple Background," Uprooting and Planting: Essays on Jeremiah for Leslie Allen, red. John Goldingay (New York, London: Continuum / T\&T Clark 2007), 153-171. 
mente som udtryk for forskellige teologiske skolers eller måske snarere miljøers arbejde med disse problemstillinger. ${ }^{11}$

I 539 f.Kr. må babylonerne overgive sig til perserriget, men det får ikke den store betydning for folk i Juda i de første år. Da perserne overtager herredømmet over den nære Orient sker der ikke de store politiske forandringer; men spørger vi Det Gamle Testamente, er der dog én afgørende begivenhed, nemlig perserkongen Kyros' edikt fra $530 \mathrm{om}$, at de bortførte i Babylon kan drage hjem. Deuterojesajas ord om, at Jerusalems hoveri er til ende og hendes skyld er betalt (Es 40,1-2), kan ses som en art religiøs propaganda for at få de mange mennesker, der havde indrettet sig i det fremmede til at rejse hjem. Om denne propaganda havde den store virkning er uvist; men under den senere perserkonge Dareios $(522$ - 486 f. Kr.) sker der noget. Dareios ønsker at sikre og udvikle sit riges yderområder i konkurrencen mod grækerne, deriblandt altså også Juda, som vi nu kan omtale som den persiske provins Jehud. Mange rejser hjem - og møder en befolkning, som har indrettet sig i det gamle land og egentlig ikke er alt for begejstrede for den tilbagevendende overklasse med dens krav om at være ikke alene de rette ejere til jord og huse, men også de rette arvtagere til den føreksilske Jahve-tro. ${ }^{12}$

\section{Refugee studies}

En lang række af Det Gamle Testamentes skrifter vidner om problemerne for de eksilerede og om konflikten mellem de tilbageblevne og de tilbagevendte. Det er en konflikt, der kan forstås gennem den moderne sociologis synsvinkel, de såkaldte "refugee studies", dvs. studier i flygtninges vilkår og bemestring af disse vilkår. Jeg skal i det følgende støtte mig til den amerikanske teolog Daniel Smith-Christopher's arbejde med eksilets teologi fra 2002. ${ }^{13}$

Smith-Christopher spørger indledningsvist: "Hvad er egentlig en flygtning?" Er det pr. definition et problem at være statsløs? Er det sådan, at kun hvis man anser grænser for at være nødvendige, bliver holdningen til grænseoverskridere negativ? Det er et helt grundlæggende spørgsmål, som kommer til udtryk i forskningen i flygtningeli-

11. For en introduktion til perioden efter templets fald og dens teologiske overvejelser, se Jill Middlemas, The Templeless Age: An Introduction to the History, Literature and Theology of the "Exile" (Louisville / London: Westminster John Knox Press 2007).

12. Til denne periode, se Lester L. Grabbe, An Introduction to First Century Judaism: Jewish Religion and History in the Second Temple Period (London: T\&T Clark 1996); Jon L. Berquist, Judaism in Persia's Shadow: A Social and Historical Approach (Minneapolis: Fortress Press 1995).

13. Daniel L. Smith-Christopher, A Biblical Theology of Exile (Minneapolis: Fortress Press 2002). 
vets sociologi. ${ }^{14}$ På den baggrund er der nemlig to holdninger i refugee studies: 15

- traumatiserede populationer kan rekonstruere eller endog opretholde identiteten fra før krisen, eller

- traumatiserede populationer har ikke stabilitet nok til at opretholde identitet, kultur og rationalitet.

Til det første synspunkt, at flygtningegruppen evner at rekonstruere sin identitet, kan føjes det kvalificerende synspunkt, at katastrofer kun bliver katastrofale for folk, når begivenhederne overstiger gruppens evne til at klare tingene, til at redefinere og rekonstruere. Man kan med Smith-Christopher illustrere synspunktet med en henvisning til moderne forhold, nemlig organiseringen af palæstinensiske flygtningelejre, så de svarer til de gamle landsbyer og storfamilier. ${ }^{16}$

En af de vigtige komponenter i den proces at genskabe mening er “...to construct a normative picture of one's past within which 'who one was' can be securely established to the satisfaction of the refugee. The refugee's self-identity is anchored more to who she or he was than what she or he has become..."17 Hertil kommer den iagttagelse, at kulturer kan blive rekonstrueret på en negativ baggrund, $\mathrm{fx}$ ved at blive betragtet som forbandede, syndige eller fordømte. Med SmithChristophers formulering: "After all, if one's suffering is because of one's own oversights, and not because of the power of the emperor and his armies, then this holds out considerably more hope about a future restoration, given appropriate spiritual recovery." 18 Det er en reaktion, der skal vise sig at være interessant i forbindelse med læsning af Jeremiasbogen.

Vedr. den modsatte opfattelse, at flygtningesamfund tværtimod går i opløsning, kan man iagttage, at under flugt går staten i opløsning, og samfundets strukturer opløses i "klaner". Smith-Christopher sammenligner med opsplitningen mellem de judæere, der var i Egypten, og de, der holdt med Babylon i den sene kongetid. ${ }^{19}$

14. Smith-Christopher (2002), 15-21.

15. Smith-Christopher (2002), 78.

16. Smith-Christopher (2002), 79.

17. Julie M. Peteet, "Transforming Trust: Dispossession and Empowerment among Palestinian Refugees", Mistrusting Refugees, red. E. Valentine Daniel og John C. Knudsen (Berkeley: University of California Press 1995), 174, jf. Smith-Christopher (2002), 80.

18. Smith-Christopher (2002), 81.

19. Se videre Smith-Christopher (2002), 81-82. 


\section{Jeremias’ Bog - en teologisk læsning}

For mig at se giver det vældig god mening at læse Jeremiasbogen som udtryk for et forsøg på at følge den første strategi, at forstærke normerne i et samfund, der potentielt er på vej til at gå i opløsning, for sådan kan det eftereksilske Jehud med megen ret betragtes. Det var et samfund, der var præget dels af et oprindeligt sammenbrud med Jerusalems ødelæggelse, hvor kongemagt og gudsmagt var sat ud af spillet, og dels af at være under et fremmed overherredømme, hvor den lokale religionsudøvelse kun bestod på baggrund af magthavernes velvilje.

Endelig var der stridigheder mellem de tilbageblevne i landet og de tilbagevendende, nøjagtigt som man finder det i moderne krighærgede lande. Tysklands genforening er ét eksempel, forholdene i det tidligere Jugoslavien er et andet; man kan blot se på problemerne for de her i landet boende bosniere med at vende hjem: har de noget at vende hjem til? Et andet helt eklatant moderne eksempel er selvfølgelig striden om Palæstina. De "hjemvendende" jøder opfattede helt naturligt landet som deres arvelod - men hvad med de palæstinensere, hvis slægt havde boet i landet de sidste 2000 år, og som med den jødiske tilbagevenden til landet fra begyndelsen af det 20. århundrede og fremefter blev drevet ud af deres huse og landsbyer, mens resten af verden så til?20

En tilsvarende virkelighed ligger altså, hævder jeg og andre, bag Jeremiasbogen. En virkelighed, hvor man over nogle århundreder måtte finde sig selv i en politisk-samfundsmæssig virkelighed, der var helt forskellig fra den, som var den oprindeligt identitetsskabende. Derfor fortalte man - genopfandt så at sige - de gamle fortællinger om, hvordan fædrene, Abraham, Isak og Jakob, var kommet østfra og havde boet som fremmede i landet, og hvordan de også var kommet fra Egypten, ført af Gudsmanden Moses og hans arvtager Josua ind i landet, hvor fjendtlige, farlige folkeslag boede. Og derfor arbejdede man ihærdigt med spørgsmålet om skyld og ansvar, gudsforhold og normativitet, sådan som vi kan se det i Jeremiasbogen.

20. En vurdering af denne situation, set fra et (kristent) palæstinensisk synspunkt, findes i Mitri Raheb, "Om at opbygge et samfund i kristetider", Genkomster: Religion og politik i Palastina, red. Kirsten Jørgensen og Peter Lodberg (København: Forlaget Anis, 2009), 89-105. 
Jeremiasbogens budskab - dystopi og utopi

Jeremiasbogens komposition viser os, hvad der er dens egentlige budskab. Det kan, med den amerikanske Jeremiasforsker Louis Stulman, illustreres sådan: ${ }^{21}$

\begin{tabular}{|ll|}
\hline \multicolumn{1}{|c}{ Dystopi } & \multicolumn{1}{c}{ Utopi } \\
I Afsløring af Judas afguderiske verden & II Genopbygning ud af ruinerne \\
1: Indledning & \multicolumn{1}{c}{ 26: Indledning - tegn på håb } \\
2-6: Frafald & 27-29: Håbets teologier \\
7-10: Tempel & 30-33: Trøstebogen \\
11-17: Pagt & 34-35: Det nye samfund \\
18-20: Privilegier & 36-45:J'lems ødelæggelse \\
21-24: Monarki & 46-51: De fremmede \\
25: Afslutning - Guds vredes plan & 52: Afslutning - en ny begyndelse?
\end{tabular}

Som det fremgår af oversigten, svarer de to dele mere eller mindre til hinanden. Første del kan beskrives som en dystopi, dvs. en beskrivelse af Judas fald. Efter en indledning, der fortæller, hvordan Juda nu for Jahve blot er én nation blandt mange, afslører profeten, hvorledes hver eneste institution, som folket har sat sin lid til, Templet, pagten, de herskende klassers privilegier og monarkiet, er blevet korrumperet og derfor nødvendigvis må gå til grunde for Guds vredes plan. Hver del indledes med en prædiken, der introducerer og kommenterer den følgende tekstblok, og på den måde fungerer som guide til det profetiske budskab. Hver eneste af de omtalte institutioner fordømmes i prædikenerne som udtryk for afgudsdyrkelse.

Anden del kan tilsvarende forstås som en utopi, en fremstilling af den kommende oprejsning, hvor Gud vil hele det brudte. Gennem selve bogens komposition understreges dens budskab, at lige så nødvendig Guds straf er, lige så nødvendigt er håbet om genopbygning. Selve denne kompositionelle struktur er naturligvis ikke nok til at virke rekonstruerende for bogens læser eller tilhører; den er blot et ydre tegn på en tankemæssig struktur. Den person, der skal deltage i rekonstruktionen af sit ødelagte samfund, må have mere end en struktur at støtte sig til. Der må også en moralsk garant til, en autoritet, der siger - og viser - at det nytter, at det giver mening.

21. Louis Stulman, Jeremiah (Abingdon Old Testament Commentaries, Nashville: Abingdon Press 2005), 14-16. 


\section{Jeremiasskikkelsen og bogens autoritet}

En sådan autoritet er profeten Jeremias. Hans bog kan læses som en eksempelfortælling, hvor profeten bliver på én gang pædagog og rollemodel. Pædagog, fordi han viser og forklarer, hvad det var, der gik galt og følgelig, hvad Israel kan gøre for at gøre det godt igen. Og rollemodel, fordi han bogen igennem lider, om ikke pga. sine egne synder, så pga. folkets. Han lider meget værre end folket, fordi han er udsendt af Gud som profet til folket, ja til hele verden, men folket og verden vil ikke tage imod ham.

Allerstørst er hans autoritet imidlertid, fordi han på en måde er ét med Gud, eller i hvert fald ét med Guds ord. ${ }^{22}$ Det ser vi allerede fra bogens begyndelse. Hvor andre profetbøger i indledningen meddeler, at de er Guds ord, forkyndt gennem denne eller hin profet, så er Jeremiasbogen if. kap. 1,1 "Ord af Jeremias, søn af Hilkija, en af præsterne i Anatot i Benjamin." Først i v. 2 tilføjes det, at det var "Herrens ord, som kom til ham, dengang Josija, Amons søn, var konge i Juda...”

Allerede fra bogens start fremhæves Jeremias altså som en afgørende person, og hans betydning understreges i den følgende kaldelsesberetning. Her hedder det (Jer 1,4-10):

v. 4 Herrens ord kom til mig:

v. 5 »Før jeg dannede dig i moders liv, kendte jeg dig,

før du kom ud af moders skød, helligede jeg dig;

jeg gjorde dig til profet for folkene."

v. 6 Jeg svarede: „Ak, Gud Herre, jeg er ung; jeg forstår ikke at tale!«

v. 7 Men Herren sagde til mig:

"Du skal ikke sige: Jeg er ung!

Men overalt, hvor jeg sender dig, skal du gå,

og alt, hvad jeg befaler dig, skal du tale.

v. 8 Du skal ikke frygte dem,

for jeg er med dig og frelser dig, « siger Herren.

v. 9 Så rakte Herren sin hånd ud og berørte min mund, og Herren sagde

til mig:

$\mathrm{Nu}$ lægger jeg mine ord i din mund.

v. 10 Se, nu giver jeg dig myndighed

over folkene og rigerne

til at rykke op med rode og til at rive ned,

til at ødelægge og til at jævne med jorden,

til at bygge op og til at plante.

22. Se hertil videre Holt (2005); Else K. Holt,"Word of Jeremiah - Word of God", Uprooting and Planting, red. John Goldingay (London: Continuum / T\&T Clark 2007), 172-189. 
Profeten har hørt sammen med Gud fra før sin fødsel, ja forud for undfangelsen. Mere end nogen anden profet er Jeremias således Guds særlige udvalgte. Esajas (Es 6) og Ezekiel (Ez 1-3) var begge voksne mænd og præster, da de blev kaldet, og det samme gælder Hoseas (Hos 1), Amos (Am 7,14) og selv Moses (2 Mos 3).23 Samuel er en dreng ved sin kaldelse (1 Sam 3), men Jeremias er kun et foster, ja nærmest ikke-eksisterende.

Videre hører vi, hvordan Gud putter sit ord næsten fysisk ind i Jeremias' mund. Dette er ganske karakteristisk for de store profeters kaldelsesberetninger. Esajas' læber bliver renset kultisk i det himmelske tempel, så han kan forkynde guddommelige ord (Es 6,6-7); Ezekiel får en bogrulle stoppet $\mathrm{i}$ halsen og spiser den og "den var sød som honning i min mund," som han siger (Ez 3,1-3). Også Jeremias får altså lagt Guds ord i munden. Dermed får han magt til at handle (v. 10), ikke alene en magt over hans eget folk, men også den universelle magt over folk og riger, som ellers tilhører Gud. Det er i den forbindelse vigtigt at bemærke de seks verber i slutningen af v. 10. Jeremias får magt af Gud til at rykke op med rode (נתש) og til at rive ned (נתץ)), til at ødelægge (אבר) og til at jævne med jorden (הרס), til at bygge op (בנה) og til at plante (נטע). Disse verber går igen en hel del steder i Jeremiasbogen og fungerer som en formel, der bruges som grundlag for temmelig forskelligartede udsagn. Det, der imidlertid er fælles for alle disse steder er, at Gud er subjekt for de seks verber. Han er den, der skaber, regerer og opretholder verden. Ja, faktisk synes det gennem hele Det Gamle Testamente, som om det netop er hans opgave par excellence at rykke op og rive ned og at bygge op og plante. Dette gælder alle steder, bortset fra i Jer 1; her er det Jeremias, der får denne guddommelige magt.

Også andre forhold i Jeremiasbogen peger i retning af, at Jeremias identificeres med det guddommelige ord. Ofte falder Jeremias' skæbne ganske tæt sammen med modtagelsen af Guds ord - eller rettere: med manglen på modtagelse. Ét sted er det helt tydeligt, nemlig i kap. 26, en fortælling om, hvordan Guds ord bliver til den skrevne Jeremiasbog, som vel at mærke ikke primært gengiver egentlige historiske begivenheder, men derimod først og fremmest er en teologisk fortælling, en legende, der er helt afgørende for overgivelsen af den guddommelige autoritet til den skrevne Jeremiasbog.

23. Ligheden med Moses' kaldelse er også medvirkende til at understrege Jeremias' autoritet, om end man kan overveje, om ikke Jeremias i virkeligheden overfører autoritet til Mosesskikkelsen; se Holt (2007). 
Assimilation med Gud-dissimilation fra folket

Hvis vi altså har etableret, at Jeremias er Guds ord - så er Jeremias i virkeligheden meget tæt associeret til Gud, for Guds ord repræsenterer Gud. Man kan altså se flg. repræsentationsrække:

$$
\text { Jeremias } \rightarrow \text { Guds ord } \rightarrow \text { Gud }
$$

eller omvendt:

$$
\text { Gud } \rightarrow \text { Guds ord } \rightarrow \text { Jeremias }{ }^{24}
$$

Dette gudsord vandrer rundt blandt folket som et eksempel til efterfølgelse, men samtidig også som én, der er anderledes end folket, netop fordi folket if. Jeremiasbogen har taget radikal afstand fra Gud gennem sin afgudsdyrkelse og ved ikke at følge Guds vilje i sine politiske afgørelser. Når folket tager radikal afstand fra Gud, må gudsordet også tage radikal afstand fra folket. Derfor understreges det gang på gang i Jeremiasbogen, at Jeremias ikke deler folkets liv i lyst og nød. Det billede, som tegnes af profeten gennem hans bog er konsistent med den indledende kaldelse. Profeten adskilles radikalt fra resten af verden - en adskillelse, der semantisk er på færde allerede i kaldelsesberetningens anvendelse af verbet at hellige (קָ) i 1,5.

Adskillelse fra folket er fx markeret i kap. 35, hvor Jeremias præsenterer og roser rekabitterne. Det er en stamme, der beskrives som den diametrale modsætning til folket, som en uopnåelig rollemodel. Rekabitterne bor ikke i byer, men i telte som på patriarkernes tid, og de drikker ikke vin, men lever et ganske spartansk og meget gudfrygtigt liv. Disse mennesker fremhæver Jeremias altså som et forbillede, men et forbillede, som folket ikke kan leve op til.

I kap. 16 præsenteres Jeremias selv inden for det samme mønster, da Gud forbyder ham at deltage i samfundslivet. Det hedder:

- Du må ikke gifte dig og få sønner og døtre på dette sted $(16,2)$.

- Du må ikke gå ind i et hus, hvor der er sørgefest, du må ikke deltage i ligklagen eller ynke dem $(16,5)$.

- Du må ikke gå ind i et hus, hvor man holder gilde, og sidde og spise og drikke sammen med dem $(16,8)$. 
Disse forbud i kap. 16 begrundes med, at Jahve vil adskille folket fra enhver form for normalt socialt liv. Ingen skal glæde sig, ingen skal sørge, og ingen skal vise sine slægtninge nogen respekt. Profeten bliver symbol for denne adskillelse; Jahve står bag straffen, men denne straf er inkarneret i Jeremias, der, som anført ovenfor, identificeres med Jahve. Skønt Jeremias' handlinger foregriber folkets handlinger, er han ikke en del af eller identisk med folket. Tværtimod er Jeremias dissimileret fra folket på samme måde, som Gud er dissimileret fra det. Atter ser vi altså Jeremias assimileret med Gud eller med hans ord, sådan som vi så det $\mathrm{i}$ kaldet til at rykke op med rode og til at rive ned, til at ødelægge og til at jævne med jorden, til at bygge op og til at plante.

Jeremias' rolle er at være adskilt fra folket. Han dissimileres langt mere gennemgribende end nogen anden profet, inklusive Moses. Moses og Jeremias har i øvrigt en lang række fælles træk. Fx ligner deres kaldelsesberetninger, som tidligere nævnt, hinanden temmelig meget. En væsentlig forskel mellem dem er imidlertid, at det til stadighed understreges, hvorledes Moses er på folkets side som mediator mellem folket og Gud, 25 mens Jeremias netop får forbud mod at mediere. I store dele af Jeremiasbogen eksisterer der ikke nogen forbindelse mellem profet og folk, mellem Gud og mennesker - det er den implicitte teologi i disse profetlegender.

\section{Dissimilation fra Gud-assimilation med folket?}

Imidlertid er der også en anden vinkel på forholdet mellem de fortalte personer, Gud, Jeremias og folket. Den er interessant nok diametralt modsat. Indtil nu har vi set, hvordan Jeremias som nærmest identisk med gudsordet dissimileredes fra folket og på den måde, som udenfor stående, kunne betragte, bedømme og fordømme folket og dermed skabe en erkendelse af, at kun gennem omvendelse kunne der skabes forandring i forholdet til Gud, og derigennem også forandring af de materielle, nationale forhold.

Men i den selv samme første del af Jeremiasbogen, som forkynder den kommende straf over folket, finder vi også nogle ganske anderledes digte, de såkaldte konfessioner. ${ }^{26}$ I disse bekendelser klager Jeremias over sin hårde skæbne som profet. Udvælgelsen af ham har gjort ham fremmed over for sit folk, og selv hans slægt er nu hans fjender, alt sammen, fordi Gud har kaldet ham. I kap. 15,15-18 klager Jere-

25. Se hertil Erik Aurelius, Der Fürbitter Israels: Eine Studie zum Mosebild im Alten Testament, (Coniectanea Biblica Old Testament Series 27, Stockholm: Almquist og Wiksell International 1988).

26. Jer $11,18-12.6 ; 15,10-21 ; 17,14-18 ; 18,18-23$ og 20,7-18. 
mias over at være dissimileret fra folket. Han ønsker det ikke; det er Gud, der har ønsket det af ham, et offer, han bærer pga. Gud, v. 15b. Det er Guds skyld, at hans fjender hader ham; det er, fordi han blev kaldet af Gud, at han ikke sidder og jubler i muntert lag, v. 17. Og ikke alene er han i modsætning til folket, han er også svigtet af Gud. "Hvorfor er min smerte uden ende? Hvorfor kan mit sår ikke læges og ikke helbredes?" spørger han i v. 18, og slutter med den bitre konstatering: "Du er blevet mig en bæk uden vand, et upålideligt vandløb."27

Gudsordet, den levende bæk, hvorfra han skulle hente sit liv, beskriver han her som tørret ind. Han stolede på sin Gud, men pga. Gud er hans liv blevet uudholdeligt. Han ønsker ikke fjendskabet over for folket, han ønsker solidariteten. I konfessionerne dissimileres Jeremias fra Gud, og man må følgelig spørge, om han dermed indirekte assimileres med folket. Er det, fordi selv profeten Jeremias klager over sin skæbne (en skæbne, som i parentes bemærket allerede fra starten er gjort klar for ham), at folket overhovedet kan lytte til ham?

I hvert fald er det, som om Guds svar til Jeremias på hans bitre klage (Jer 15,19-21) i sidste ende også kan tale til folket, selvom det fra begyndelsen ikke lyder sådan:

v. 19 Hvis du vil vende om, lader jeg dig vende om,

så du kan stå i min tjeneste...

v. 20 Over for dette folk gør jeg dig

til en stejl bronzemur;

de skal angribe dig,

men ikke besejre dig,

for jeg er med dig...

"Dette folk," som Jahve vil styrke profeten overfor (v. 20), er i forhold til Jeremias Judas folk, men for de følgende generationer af judæere, der hørte disse klager læst højt, er "dette folk" babylonerne, perserne, grækerne, romerne. Hvor der på overfladeplanet er en direkte forbindelse mellem Gud og profeten Jeremias, der udelukker folket, så skabes der gennem Jeremias' klage en forbindelse, en assimilation, mellem profet og folk, der ganske vist ikke udelukker Gud, for klagen er henvendt til ham; men som lægger skylden for nøden på ham, ikke på folket. Det er denne skyldfordeling, Gud afviser i sit svar, v. 19-21. Dermed er skylden fordelt, og Gud er frikendt. Men der er også skabt handlemulighed for folket gennem omvendelsen.

27. Om vandet som grundlæggende metafor i Jeremias' Bog, se Else K. Holt, "Er Gud det levende vand?", DTT 66 (2003), 259-269. 
Endnu mere påfaldende bliver den sidste af profetens klager, Jer 20,14-18, dog, for den forbliver ubesvaret af Gud. Denne klage indeholder atter profetens klage over sin skæbne, men her drager han en direkte sammenligning mellem sig selv og de ødelagte byer:

Forbandet den dag,

jeg blev født,

den dag, min mor fødte mig,

skal ikke være velsignet.

v. 15 Forbandet den mand,

der bragte min far det budskab:

„Du har fået en søn!

og gjorde ham meget glad.

v. 16 Det skal gå den mand som de byer,

Herren ødelagde uden barmhjertighed.

Han skal høre skrig om morgenen

og kampråb ved middagstid,

v. 17 fordi han ikke dræbte mig i moderlivet,

så min mor blev min grav

og hendes moderliv svangert for evigt.

v. 18 Hvorfor kom jeg ud af moderlivet

for kun at se ulykke og sorg,

så mine dage svinder hen i skam? (Jer 20,14-18)

I denne klage er der en direkte identifikationsmulighed for et folk uden byer, et folk uden fremtid, et folk, der ser sig som forladt af Gud.

\section{Afslutning}

Hermed er der også skabt grobund for den opbygning af en positiv, national identitet, som jeg omtalte ovenfor, en (gen-)opbygning, som Jeremiasbogen i sidste ende skal resultere i. Louis Stulman hævder, som nævnt ovenfor, at bogen består af to dele, hvoraf den ene skal nedbryde Israels tro på tomme, menneskelige institutioner, tempel, kongedømme, udvælgelsesteologi $\mathrm{fx}$, mens den anden skal opbygge tilliden til, at Gud er den sande, universelle konge, og at der skal opbygges et helt nyt gudsforhold - det, Jeremiasbogen kalder en ny pagt. Jeg er ikke sikker på, at Stulman har helt ret; for mig at se er der langt mere dom i Jeremiasbogen end løfte om frelse. ${ }^{28}$

28. Se videre Holt (2003); Else K. Holt, "King Nebuchadrezzar of Babylon, My Servant, and the Cup of Wrath: Jeremiah's Fantasies and the Hope of Violence", Jeremiah (Dis)placed, red. Pete A.R. Diamond \& Louis Stulman (London: Continuum / T\&T Clark, under udgivelse). 
Men afvises kan det ikke, at bogen også indeholder trøstende ord, der kan sammenlignes med Deuterojesajas ord fra indledningen: “Trøst mit folk, trøst det, siger jeres Gud." I Jer 30-31, den såkaldte "Tröstesbüchlein", hedder det således bl.a.: "Men du, min tjener Jakob, vær ikke bange. siger Herren" (Jer 30,10). Det er interessant at iagttage, hvordan teksten i disse kapitler veksler, også grammatisk, mellem at henvende sig til en mandlig tilhører, Jakob, Israel, Efraim, og en kvindelig, Zion, Israels jomfru, Rakel. Trøsten henvender sig til både mænd og kvinder, blinde og halte, svangre og fødende. Dem, som ikke har kunnet hjælpe sig selv, vil Jahve nu hente hjem. ${ }^{29}$ I 31,28 optræder de seks signifikante verber fra Jer 1,10 som det eneste andet sted i Jeremiasbogen i deres fulde omfang, og her som et løfte til folket: "Ligesom jeg vågede over, at de blev rykket op med rode og revet ned, jævnet med jorden og ødelagt og led ondt, således vil jeg våge over, at de bliver bygget op og plantet, siger Herren.” Og straks herefter finder vi løftet om en ny pagt engang i fremtiden, der bliver ubrydelig, fordi Gud selv vil lægge sin lov i deres indre og skrive den i deres hjerte. Denne pagts ubrydelighed understreges af de afsluttende henvisninger til Guds skaberkraft som garanti for den.

Skal der opbygges en national identitet af et frustreret folk, der ikke kan vende tilbage til en oprindelig identitet, når tempel og konge er borte, og de folk, der bor i landet, er fjendtlige, 30 behøves autoriteter fra fortiden, $f x$ profeten Jeremias, og der behøves en overlevering, man kan bruge til noget. Derfor får vi gennemskrivningen af Jeremiasbogen $\mathrm{i}$ århundrederne efter Jerusalems fald. Og endelig behøves der en sikkerhed, som man får gennem Guds løfter, givet gennem denne autoritet, løfter om, at der kan gøres noget: "Hvis I selv omvender jer, så vil jeg være med jer. Og den magt, som ødelagde jer, det var en magt, som jeg, Gud, selv hidkaldte, og som jeg kan - og vil - ødelægge igen," som det understreges i Jeremiasbogens afsluttende orakler mod Israels naboer og fjender (Jer 46-51).

Det er budskabet til dem, der ville genopbygge Juda - og som det på sin vis lykkedes for, selvom der aldrig mere kom en konge af Davids slægt til at sidde på tronen $\mathrm{i}$ Jerusalem.

29. Se fx 31,7-9 og sammenlign med metaforikken i S1 23.

30. Det bør ikke overses, at de hjemvendende og de tilbageblevne engang hørte sammen som ét folk, og at sagen med lige så god ret kunne ses fra de sidstnævntes side; men synsvinklen i denne artikel er, som i Jeremiasbogen, de hjemvendende vinderes. For en introduktion til tabernes synsvinkel henvises til fx Berquist (1995). 